\title{
Women Managers and Their Personal Barriers for Upward Mobility in Private and Public Sectors
}

\author{
LAKMINI V K JAYATILAKE \\ Department of Commerce and Financial Management, University of Kelaniya \\ lakminij@yahoo.com \\ P A P SAMANTHA KUMARA \\ Department of Marketing, University of Ruhuna \\ samanthak@badm.ruh.ac.lk \\ PIYASIRI WITHANAGE \\ Department of Economics, University of Ruhuna \\ piyasiri@econ.ruh.ac.lk \\ R LALITHA S FERNANDO \\ Department of Public Administration, University of Sri Jayawardenepura \\ lalithaf@yahoo.com
}

\begin{abstract}
Women's participation in the paid workforce is one of the most significant social changes of the last century. Therefore, significant progress has been achieved by women with their increase movements into the occupations and the proportion of women in management of different levels of the organizations has increased. However, towards the end of year 2012 the proportion of women in decision making is very low and still there are only around 20 per cent women are represent the managerial positions. Qualitative case study methodology was used to answer the question 'what are the perceived personal barriers that inhibit to career development of women managers in Sri Lanka'? By this study, it has been analyzed the experiences of 40 Sri Lankan women who are holding senior-level management positions in five public and five private sector organizations in the occupational categories of Education, Accountancy, Engineering, Insurance, Banking and Medical Service. The Grounded Theory analysis method was applied to analyze the data. The study found out that there are barriers in organizational support, number of task and working load, nearest colleagues and friendship and fellow managers and support.
\end{abstract}

Key Words: Women, Public Sector, Private Sector, Managers, Personal Factors. 


\section{Background of the Study}

Like many other Asian countries, labour force statistics of Sri Lanka gathered through the latter part of the $20^{\text {th }}$ century demonstrate an increase in the number of women in paid work. The increase in number of women professionally educated and entering management will change the social fabric and accept new role definitions for women and men. As a result of these changes the women in management profession perform and achieve the barriers to corporate ladder would decrease and accordingly new opportunities be created. The proportion of women in management of different levels of the organizations has increased and the number of women in the administrative and management categories decreased during the period of 1980-1990 (Department of Census and statistics 1995). Thus in 1980 there were 452 women and in 1985 there were 645 women in administrative and management categories. This is a 40 per cent increase in women in administrative grades (Department of Census and Statistics, 1995) during this period. Silva (1985) surveying the placement of women in higher positions noted that in 1981 there were no women in the posts of Secretary or Additional secretary. However in 1990 there were $43 \%$ women in administrative grades and this is a 43 percent reduction during the period of 1985-1990(Department of Census and Statistics 1995). The later decrease of 43 percent perhaps reflects the voluntary retirement option being exercised in public sector. The proportion of the women employees in the administrative grades remained low and stagnant at 13 percent in 1990.

While women are thus concentrated at the bottom of the occupational hierarchy the access of qualified women to the highest decision- making positions in the public and private sectors continues to be impeded by the 'glass ceiling' created chiefly by gendered norms and consequently by conscious or unconscious gender bias (Jayaweera2000). The percentage of the female labour force in senior management administrative and professional positions has declined from 11.7 percent in 1994 to 8.7 percent in 1999 (Department of Census and Statistics, 2000).

While women are concentrated in specific professions vertical segregation is also evident. Women are virtually absent in decision making positions in areas such as engineering, construction, automobile, food and beverages and information technology (Gamaathige and Abeysinghe 2004; Ratnasahapathy 2006; Jayaweera and Wanasundera 2006). There are no legal barriers to obtaining employment in the public sector today although there were discriminatory 
practices restricting the entry of women into the Sri Lanka Administrative Service, the Government Clerical Service and to the Shroff Service until 1978 (Section 16 (2) of the 1972 constitution added that 'in the interests of such services, specified posts or classes of posts may be reserved for members of either sex. The 1978 Constitution of Sri Lanka recognized gender equality and freedom from discrimination). However women's representation at decision making and leadership positions in administrative structures at the central and provincial levels, and in educational institutions is still not on par with men or commensurate with their educational and professional achievements (Jayaweera et al., 2008).

The statistical overview of women in the workforce demonstrates that public and private sectors show an increase in the numbers of women managers over time. However women are more numerous in the public sector and are in more senior positions than in the private sector. However towards the end of the $20^{\text {th }}$ century the participation of women in decision making at various levels in the public and private sectors have increased only by 20 percent (Department of Census and Statistics 2000). The ILO study (2004) shows that while women's share in total employment was around 47 per cent their share as administrative and managerial workers at just over 20 per cent was less than half of this proportion. This includes senior level public servants, policy makers, ambassadors, scientists, University Registrars, Deans, media executives and top executives of the private sector (Jayaweera et al.,2008).

There has been sufficient research focused on leadership application including exploring gender differences in leadership and management. Effective managerial behaviors, requirements for successful leaders, and feminine management have been the topics of various articles in both professional and popular media. However, most of these sources determinants of managerial advancement have not been well established, as only a few studies have examined broad range of personal and situational variables. This study seeks to build the knowledge base specifically for the 'feminization of management' field by exploring and describing the specific development and barriers experiences of women leaders. Exploring women's unique needs and experiences of leadership roles can help for success in leadership and management. 


\section{Objectives of the Study}

The problem of the glass ceiling is that women management face and the invisible barriers that prevent them from advancing upwards to higher levels of the managerial ladder in most countries of the world, have been analyzed and discussed extensively in a large number of research articles (ILO,1998). The gendered analysis of organizational cultures is considered, as reasons are sought for the higher representation of women in public sector, as compared with private sector management. The general objective of this study is to examine 'whether women have become discriminative in the arena of top management in the public and private sector organizations in Sri Lanka'. Accordingly the specific objectives of the study can be indicated as follows.

The female participation rate in the public and private sector labour force in Sri Lanka has increased from 55.1 per cent in the 1990 to 55.2 per cent in the 2009 s (Department of Census and Statistics 2009). Despite such economic achievement, relatively little research has been done on the status of women, the general working environment of women in management, wage differentials, personal differentials, sexual segregation, discrimination, and perception and attitudes towards women as managers, etc. Based on this, another specific objective could be raised as 'to explore the barriers that impede career development of Sri Lankan women managers in public and private sectors'.

\section{Research Questions}

The problem identified show that, the gender differences in the level and type of formal education and in participation in the labour force are rapidly disappearing (Jayaweera 2000): but the rate of advancement of women into higher positions in organizations is relatively slow. Even though there is an increasing number of women who enter the workforce and an increasing number of managerial positions women's access to leadership positions remains limited (Eagly et.al2003). The barriers for upward mobility of women are the cultural, situational and the personal factors. Accordingly this research examines the following research questions.

1. What are the personal barriers that inhibit to career development of women managers in Sri Lanka?

2. What are the policy measures to overcome these barriers? 


\section{Literature Review}

\section{Women Managers and Career Motivation}

A career can be conceptualized as having two components; employees' objective for participation in work and their subjective commitment to work (Pulkkinen et al., 1999), while motivation relates to the strength, direction and persistence of an individual's behavior. Based on this broad conceptualization London (1983) has proposed a theory of career motivation which suggests that individual characteristics and situational conditions are the key predictors of individual career behaviours and decisions. Career motivation can be grouped into three domains: career insight, career identity and career resilience each with several components. However men and women have expressed differences in career motivation.

The concept of career insight relates to the realism that individuals have about themselves and their careers. Those who are high in career insight have realistic perceptions of themselves and the company and relate these perceptions to career goals (London, 1983). Men commonly make occupational moves that provide greater promotional opportunities and allow their opportunities to take advantage of their seniority. The concept of career identity is the extent to which employees are attached to their work. It is related to satisfaction derived from the current job, primacy of work and the desire for upward mobility (London, 1983). Work often has more primacy for non-married individuals versus married individuals.

The concept of career motivation is explored in the study through three dimensions of career resilience, career insight, and career identity (Leung and Clegg, 2001). Overall younger executives had higher levels of career motivation and were striving to attain additional responsibility and authority in work assignments; while senior executives were concerned with holding on to their previous accomplishments and competence in their occupational role. Jawahar and Hemmasi (2006) results suggested that organizational support for women's advancement is related to turnover intentions. This relationship is mediated by employer satisfaction. Burke et al., (2006) purpose of the study is to examine the relationship of the perceived presence of organizational practices designed to support women's career advancement and their work attitudes and satisfaction and their psychological well-being. Women reporting 
more supportive organizational experiences and practices were more engaged in their work, more job and career satisfied and indicated greater levels of psychological well-being.

\section{Women Managers and Job Commitment}

According to the Lowthom et al., (1996) examines comparative levels of job satisfaction, organizational commitment and mental health. Results suggest that women managers see their organizational worlds in a significantly more positive light. Contrary to social perceptions and stereotypes, Omani women in leading positions are highly motivated and ambitious (Al-lamky 2007). Burke and Mckeen (1997) compare managerial and professional women with and without mentors on a variety of measures. These include personal demographic and situational characteristics, work outcomes and aspects of psychological well-being. According to their study women having mentor relationship were younger, in higher level positions, had shorter job tenure, worked more hours and extra hours per week and attached higher priority to their careers.

According to Headlam-Wells et al., (2006) study, mentees showed improvements in many key employability skills. For example, their ability to identity their weaknesses and ways to develop professionally improved substantially as did their networking skills and ability to identify their strengths. Mentors also indicated that women had experienced development, for example, greater self-awareness, increased confidence, improved reflective skills and development online skills. Mentoring is frequently cited as playing an important role in the career development of successful women managers (Headlam-Wells, 2004).

\section{Women Managers and Work-Family Interface}

Rana et al., (1998) paper examines the experiences of British South Asia full-time managerial or professional women combining work and family. Managerial or professional British South Asian women are subjected to the same cultural family commitments and expectations as other nonprofessional British South Asian working women. Role conflicts for career women constitute a major source of stress and need for developmental planning and can result in costs to efforts to meet personal needs (Zunker, 2002). In recent years, however, women's career and family expectations have taken on a more complimentary relationship in which women have begun to pursue both sets of goals for work and family without feeling as much pressure to choose one over the other and compromise their personal professional goals (Grant, 2000). Moore et.al 
(2007) found that managerial women reported working significantly more in the home; measures of conflict and strain, however, while showing some effect were not impacted to the degree that managerial women's combined number of work and home hours per week might suggest.

There are certain differences in the provision of work-life balance practices and women's participation in the labour force among European Companies (Straub, 2007). A positive influence of work-life balance policies and practices on women's career advancement into senior management positions was confirmed in only one case-the payment of an additional amount for maternity leave. The greatest obstacle to achieving work life balance is seen as the 'long hours' culture in which availing oneself of flexible options is incompatible with holding a senior management post (Drew and Murtagh, 2005). Many of the senior men have followed the 'breadwinner' model by being able to delegate family and caring activities to their wives. This option has not been possible for the majority of women in senior posts.

\section{Research Methodology Overview}

The research approach for this study was a qualitative method with a feminist orientation for the purpose of describing and exploring women leaders' experiences of their perceived barriers for upward mobility. Characteristic of exploratory research, conducted within a qualitative pattern, the methodology was designed to allow the researcher to build rich description of caseorganizations management practices were developed, created and maintained which 'filled and worked' participants' perspectives ( Glaser, 1992). Using qualitative methods and a feminist perspective to develop and explore individual leader perspectives and experiences can assist to more fully understand the question of women's leadership roles: a perspective lost in contemporary women in management research. The intent of the study is to interview 40 women managers in public and private sectors. The sample was a purposefully selected group of 20 women from the public sector and 20 women from the private sector who hold senior-level management positions in the fields of Education, Accountancy, Engineering, Insurance, Banking and Medical Service. To gain these perspectives, qualitative interviews are typically used. The researcher develops semi-structured, open-ended interview questions which provide the participants the opportunity for in-depth discussion. When how and why questions are used, case study, experiments, or histories are appropriate (Yin, 2003). The current study is exploratory and uses how and why questions. Yin (2003) posited that when the relevant behavior of the 
participants cannot be manipulated and contemporary events are examined, case study is the preferred research design; both are conditions of the current research. A Grounded theory (Glaser, 1992) data analysis method was used to explore and analyze the interview data to discover the central themes and meanings the women ascribe to their perceived barriers for upward mobility. It is considered particularly suitable to the opening of a relatively new area of study and to the goal of generating valid data for a limited number of cases, rather than generalizable data for a whole population. As a means of triangulation to ensure research validity (Yin, 2003), the women were asked to review the analysis and make comments, edits, and additions to authenticate and validate the analysis used in the final report. This study has triangulated the investigation by methods of observation, interviews and documentations. The method is designed to give voice to the participating women leaders in the tradition of feminist research perspectives. According to the Grounded Theory, sub topics of the cases which have been discussed in the following section are found. It was decided that the following set of criteria would help the researcher, when in the field to make objective decisions about the women in the organizations were approached.

\section{Discussion and Analysis}

\section{Job Satisfaction}

Personal factors are the common obstacles faced by the women when they accede to top positions. Examination of this problem provides an opportunity to identify gender differences in leadership effectiveness and leadership behavior and styles. All the interviewees spoke extensively about the attributes of their personal factors on women in management. The personal factor profile of the interviewees has the following attributes.

Job satisfaction is a pleasurable or positive emotional state resulting from the appraisal of one's job or job experience. Job satisfaction is a result of employees' perception of how well their job provides those things that are viewed as important. In addition, career identity is linked to job satisfaction. Extrinsic features of job satisfaction include salary level, social aspect, company policy and administration, working conditions. Intrinsic features are associated with positive work experiences, which include, opportunities for advancement, meaningful and challenging work, achievement and recognition. 
However, many researchers suggest there are gender differences in job satisfaction. Some studies have reported that men express greater concern than women for instrumental work outcomes, while women placed greater emphasis on affective work outcomes (Leung and Clegg, 2001; London, 1983). Women are traditionally excluded from management jobs because they are judged less serious, less highly motivated than male employees (Marshall, 1984). According to Brief and Oliver (1976), no significant pattern of male-female differences was found, after counting for variables of occupation and organizational level motivation.

In our study women in the sample appear to be highly motivated and highly committed to their careers. Research here has often found women reporting higher levels of job satisfaction. In this sample, women report higher levels of job satisfaction on both extrinsic and intrinsic features. This satisfaction is further supported by loyalty expressed to the organization, where women managers feel significantly more committed to their organizations.

\section{Judgment of Women's Work Performance}

To understand the judgment of women's work performance it has asked the question "Do you think that women receive more unfair judgment of their work performance than women?"Same answer was given by almost all the women in this regard. According to their views, if they are working with commitment, efficient and effective manner proper judgment will be given by others. It means that, there is no discrimination in evaluation of performance. According to them they are very efficient and correct. However, another lady Doctor told entirely different views in this regards. According to her,

"In some circumstances, unfair judgments are given to women managers by other, especially during the pregnant period. Most of the top managers prefer if the males are coming forward than women. Mentally and physically we are working hard. But sometimes, some officers have negative attitudes on women managers".

To further clarify this matter few male managers were interview and according to their opinions, there is no any discrimination when evaluating performance of women officers. Accordingly, it was observed that, the judgments of the top level management are given equally and fairly for the women officers when evaluation of performance is done. However, previous research was not found in literature survey. 


\section{Accomplish More and Push Hard to be Promoted}

Another question was the "Do you think, as a woman, you must accomplish more and push hard to be promoted?" According to the views of the majority of the public sector women managers, same procedures are followed by the management when promotions are given to women officers. Accordingly promotions are given on the base of efficiency and the paper qualifications. Therefore, there is no need to get separate effort in this regard. Promotion is given as usual. According to the views of interviewed five women managers in private sector, the works should be done very hard to get promotions. Because, they are always compared with males.

A promotion is the appointment of a women who is currently working, in the organization to a job that is higher/greater than the job being performed by her. It is an advancement of women to a better job. Promotion as an upward change of position, normally involving greater responsibility and different duties from those of the present position and is a move of an employee to a job within the company which has greater importance and usually higher pay. Due to these reasons, promotion is an important matter to almost all the women in the sample. According to the agreement of thirty five women, accomplish more and push hard not applicable for that purpose.

\section{Professional Development at Work}

Training and development are organizationally directed experiences designed to improve employee competency levels and enhance organizational performance. The literature suggests that managerial advancement is positively related to human capital credentials. More specifically, women's advancement to top management is directly related to their increased knowledge and skills and professional development opportunities made available to them throughout their careers. According to the interviewed to women, the opportunity for their professional development is less due to work related with their children at home.

However, according to many women, professional development is a necessary thing. Therefore, the significant should be given that purpose too while on engage with other works. Some has even tried to train their juniors. Expressing the views Mrs. PN mentioned that, 
"The institute particularly does not help for professional development. We do those things by ourselves. We should follow chartered engineering. We were advised by our seniors. We are also giving for lower grade officers without considering gender differences".

Expressing views by another women Director,

"In our institution the necessary training is given to the employees for their professional development. Financial assistance is also given by the institute for such outside courses. Professional development can be obtained if we have commitment".

According to Jamali (2006), the women interviewed seem satisfied with opportunities for career development made available in the context of Lebanese banks. These findings were confirmed in our study. A good percentage of women managers ( 80 per cent) considered that the opportunities for professional development made available in the context of their organizations were adequate.

\section{Domestic Responsibilities and Double Role}

The expectations and values in work place cultures may conflict with the values and expectations of work and family for Sri Lankan women. The experience of time and having to work long hours as a sign of commitment appears to be difficult for Sri Lankan women as for many other women, as they have an additional burden to prove their competence, especially as they face barriers to their career progression. The pressure of having to fulfill multiple work and family roles and responsibilities was particularly difficult for the managerial or professional women

My questions aimed to find out how the society and family respond to the women who want to balance, the demands of home and career. In general, women were respected by their family members and there was no significant opposition to their assuming a dual role as homemakers and working women. On the other hand, involvement in wage work increased women's autonomy and rearranged relations in the patriarchal Sri Lankan household. Support from families and husband were very important to the managerial careers of the women in study. The married women had dual- career marriages. The spouses held a variety of professional positions and had demanding careers. The married women perceived that their husbands to not feel threatened by their work, and two third of them strongly emphasized that their spouses were the key to their success. For example, 
"My husband is eager to see that I study further, it was only eight months to my son when I received a foreign scholarship for my PhD. At this moment my husband took the entire responsibility in looking after the child and allowed me to proceed. With great reluctance I was compelled to leave the child and go abroad, as I had to give priority to my career progress".

However, according to ten women managers, work family role is a conflict. One woman expressing her views said that,

"A woman, there are many work in the family. Even I did my PhD under this situation. During that period I continuously work from $8.00 \mathrm{am}$ to $4.00 \mathrm{pm}$ and after arrived home, I did not involve with my academic works".

Next questions are 'Do you think women receive enough organizational support in order to manage their professional work and their domestic responsibilities' and 'Do you think you need more support than you receive to manage your double role'. According to many women there is no support from the institution to do dual role in the office and at home. Such dual role is managed by her. However, they are not expecting such support from the institute. They feel that it is not fair to expect such help from the organization. Expressing views regarding support from institute Dr. LV mentioned that,

"There is no particular help receiving. Government sector has given ten months maternity leave. There is no a day care center at our hospital. There is a mutual understanding for the women who have children less than one year age. But not for women who have older kids".

According to another women she was not received any support from the organization. Expressing views in this regard Mrs. RS said that,

"Not particular support receiving. There is 'quarters'. It should be in a waiting list to get quarters. Informally home work is also done (taking the children to classes). In this field I am very tired when I reach home after office. There was not even a servant during last few months. Husband was also very busy with his job in the ministry, full day meetings. In such circumstances, I have to do everything by myself".

Role conflicts for career women constitute a major source of stress and need for development planning and can result in costs to efforts to meet personal needs (Zunker 2002, Grant 2000). 
Women are usually achievement oriented but their progress often suffers setbacks due to family responsibility. These findings affect ten of the women in our sample. The domestic and motherly responsibilities indirectly affect the career progression of women in management by causing delays in obtaining qualifications. However, according to the replies given by most of them who were in the sample, these findings are not confirmed. As per twenty two of the women however much the work load is, they try their best to obtain the qualifications required for their career progress. Although working women get a lot of encouragement and support from their husbands to move up in their career, they do not get any domestic or household help from them. According to the majority of them they did not receive more organizational support in order to manage their professional work and their domestic responsibilities.

\section{Number of Task and Too Much Work to Do}

According to majority of the women interviewed they have huge work load to do. Due to this reason they have work stress. However, it was observed that they are doing all the works with prefer. Expressing views in this regard Mrs. SP mentioned that,

"Really I feel that the work load not sufficient for me. I can do more works"

However, according to thirty four women, there are huge work load to do and five women held intermediate opinion. Expressing views one of the Deans Prof. PG speaking,

"My work load is too much. I have to look after my Department's problems too, while I am performing the duties as the Dean. In addition going for research, setting and moderating question papers, marking sometimes more than 200 answer scripts overnight etc.. Service functions are going on. Only the lab in Sri Lanka which distributes production to the general public belongs to our department".

Expressing views by another Provincial Director said that,

"This is one of the highest population density areas. Most of the people are having a dog or a cock. I have to go to the field after 10.30. If I want I can reduce my work load reducing response to the people's request. But, I am not doing so. I help to all. Therefore work load in much high"

One women holding intermediate opinion said that, 
“There no more works. We can't work confining to a list of duties. I have to maintain the coordination when specially working Kandy and Colombo. If anybody asks for a help we have to do it. If not there is no professional survival. In addition to work in this institute, we have to involve with the duties of other parallel institutes and other top level officials. So, we have to balance our duties".

However, according to the majority of the women interviewed, number of tasks and the work load is much more. This situation has been indirectly affected for their career development. However, there is no evidence of previous research in this regard. Therefore, this personal factor can be considered us a topic in future research.

\section{Psychological Well-being (Life Satisfaction, Psychosomatic Symptom, Emotional Exhaustion)}

The stress is increased with the high work load. Due to this reason, psychological well-being disappears. This situation is badly affected for dissatisfaction in life, psychosomatic symptoms and creation of emotional exhaustion etc. According to the views of a Regional Director in this regard,

"The job in the Irrigation Department is a good thing to live with happy. Because, we have to visit to the paddy fields, jungle and lake etc. when working in the field.Therefore no sick".

According to another woman she has had migrate before she hold the management position. However, it has been disappeared of enroll with a management position. Another manager was a woman who done insight meditates. Therefore, she said that she is encouraged person. Therefore not mush sick, and according to her, she maintains mental stability.

Accordingly, all agreed that, even though the work load is high, it has not greatly affected to their health. It was observed that women managers interviewed are in good psychological wellbeing. This situation was further confirmed observing their medical leave. However, there is no evidence of previous research in this regard. 


\section{Different Problems Deal}

Women managers are facing for variety of problems while on service. When the problems are too much it may be resulted to dissatisfaction and to leave the organization. At most all the women managers have been accustomed to face for variety of problems and solve them. One woman has been solved at least one specific problem when they worked. One of the woman managers explaining her experiences said that,

"Many problems are coming. Especially many problems are created by some of the politicians". Further, she showing a document as an example said that "This document I received today. According to this document I have to answer for the questions of how to find the animal and how to provide the financial grants for this project. I have to spend much time to answer for these questions giving up my other duties. Because I should give priority for that document. We have to deal with such problems".

It was observed that, out of all the women manager interviewed, women managers working in universities are facing many problems than others. According to one woman manager in an university,

"We have to face for numerous problem of students, academic and non-academic staff, and the administration. For an example we had to shift to a new building. It was not properly arranged. In some places of the building there are no power points. Even the Registrar is not aware about it. After the post mortem of animals, bringing and pulling here. So we can't work here due to bad smell. I have to handle all these things. It is very difficult to work with administration staff particularly with newly appointed Assistant Registrars".

Accordingly, it was observed that, they have to deal with variety of problems when they are performing their duties. But, those are not personal problems. However, it was observed that, they are carrying on their duties solving the problems they face. It was confirmed in interviews too.

\section{Nearest Colleagues and Friendship}

Nearest colleagues and friendship are essential when doing a job. Because, such colleagues and friendship are necessary to prevent loneliness at the job and get support to solve some problems. 
The answer given by one fourth of the women managers were that, even though, there are some problems with peer groups, works are carrying on cooperative manner. But they are not concerned as friends and not associated with them as friends.

According to another two fourth, there is no any friendship with nearest colleagues. However according to another one fourth of women managers, they associate with nearest colleagues as friends to delegate some duties in an urgent situation and solve some problems. According to the views of the majority of women managers is that there are no any nearest colleagues and friendship.

\section{Fellow Managers and Support}

Fellow managers and support is also an important aspect when doing a job. Because it is difficult to go forward in aparticular urgent situationwithout the support and advice from them. According to one third support is given by fellow managers. For an example of a Dean, when there are some problems in a faculty, other Deans are not talking against faculty and they are giving their support to solve such problems.

Expressing views in this regard Mrs. PJ said that,

"I can't meet fellow managers other than through the telephone. Occasionally they are meeting about once a month when participating in a meeting. When a problem arises solutions are found through telephone interactions".

According to two third fellow managers are not meeting regularly. Therefore their support is in minimum level. However, all most all agreed that, their support is necessary. Accordingly, they expect more support from fellow managers than receiving at present.

\section{Feel Alone in the Job}

The last question asked related to personal factors was "do you feel alone in your job". Different answers were given by different women managers for this question. According to two fourth of women managers, they do not feel aloneness when doing the job and according to another two fourth of women managers, they feel aloneness when doing their job. Accordingly one woman said that, 
"In the field of insurance only I am here. So I feel alone particularly in cases of out of my field".

In an another occasion, speaking Mrs.RP said that,

"I feel alone. I can't meet my friends or fellow managers other than through telephone. I have not a friend nearby. Not a regularly meeting group".

Accordingly, one second of the women in the sample feels alone and to other one second of the sample not feels alone when they are doing their job. However there are no evidences of previous research in this regard. Therefore this is another important area to do a research. Personal factor has changed significantly to accommodate women as managers. Our study looked at a number of different criteria for managerial effectiveness and found out that there are barriers in organizational support, number of task and working load, nearest colleagues and friendship and fellow managers and support.

\section{Summary and Conclusions}

In the emerging realities of globalization and liberal business environment of Sri Lanka and the influx of women into the labour market create more opportunities for Sri Lankan women to reach management positions. As a result of these changes, the women in management perform and achieve the barriers to corporate ladder would decrease and new opportunities would be created. Therefore, the proportion of women in management of different levels of the organizations has increased. However, the statistics presented in Department of Census and Statistics indicate that only around 20 per cent of employees who have reached the highest decision making positions in the public and private sector are women. Towards the end of year 2012, the participation of women in decision making at various levels in the public and private sector is very low and the women in the highest management levels have increased only by 20 per cent. The study found that smooth progress in upward career mobility was impeded by personal factors affect on women in management. This study looked at a number of different criteria of personal factors for managerial effectiveness and found out that there are barriers in organizational support, number of task and working load, nearest colleagues and friendship and fellow managers and support. 


\section{Recommendations}

1. Introduce special programmes to increase their self-confidence and capacity for management at any level.

2. Policies and programmes have to be focused to promote equitable gender relations and division of labour within the household and the economy.

3. Women in leadership positions should engage in self-development programs in order to update their knowledge, enhance their professional and leadership skills and develop other personal skills that would make them efficient in male organizations. In addition, engaging in a mentoring relationship could enhance self-development.

4. A series of measures related to improving working conditions for women are recommended. This included: the employment of more women managers: more flexible working conditions with more home-working, flexi-time, job-sharing, workplace childcare, career breaks and flexible contracts: the identification of role models through team working: workplace job shadowing and secondments: a greater focus on job specifications rather than person specifications: and the restructuring of bonus schemes.

5. Policy decisions as well as more accurate societal beliefs can be informed with greater understanding of the explicit challenges managerial women as well as all working parents of children of various ages confront when navigating the arenas of work and home.

\section{References}

Al-Lamky, A. (2007), Feminizing Leadership in Arab Societies: the Perspectives ofOmani Female Leaders, Women in Management Review, Vol 22, No 1, MCB UP Ltd, pp 49-67.

Brief, A.P, Oliver, R.L (1976), 'Male-Female Differences in Work Attitudes AmongRetail Sales Managers', Journal of Applied Psychology, Vol.61, No. 4, pp 526- 528.

Burke, R.J and Mckeen C.A (1997), Benefits of Mentoring Relationship among Managerial and professional women: A Cautionary Tale. Journal of VocationalBehaviour 51, 43-57.

Burke, R.J, Koyunch, M and Fiksenbaum, L (2006), Organizational Practices SupportingWomen's Career Advancement and their Satisfaction and Well-being in Turkey, Women in Management Review, Vol 21, No 8, MCB UP Ltd, pp 610-624. 
Department of Census and Statistics (DCS) (1971), Census of Population and LabourForce Survey, Colombo.

Department of Census and Statistics (DCS) (1990)-(1995) Sri Lanka Labour Force Survey(s) Quarterly, Colombo.

Department of Census and Statistics (1995), Women and Men in Sri Lanka, Colombo.

Department of Census and Statistics (DCS)(1998) Census of Public and Semi Government Sector Employment, Summary Report, Colombo.

Department of Census and Statistics (DCS) (2000) Sri Lanka Labour Force Survey(s)Colombo.

Department of Census and Statistics (DCS) (2007), The Sri Lanka Women, Colombo

De Silva, Wimala (1985), Women and Decision Making During the U.N. Decade for Women, Progress and Achievements of Women in Sri Lanka, pp:111-146, Colombo: Centre for Women's Research.

Drew, E and Murtagh, E.M (2005), Work/Life Balance: Senior Management Championsor Laggards? Women in Management Review, Vol 20, No 4, MCB UP Ltd, pp. 262-278.

Eagly, A.H.., Johannesen-Schmidt, M.C.., Van Engen, M.L (2003), Transformational, Transactional, and Laissez-Faire Leadership Styles: A Meta-Analysis ComparingWomen and Men, Psychological Bulletin, 129(4), pp 569-591.

Gamaathige, A and Abeysinghe, S (2004), Status of Female Employment in the Private Sector, A Case Study of Sri Lanka, Colombo: The author.

Glaser, B.G(1992), Basics of Grounded Theory Analysis: Emergence Versus forcing, Sociology Press, Mill Valley, C.A.

Grant, D.F (2000), The Journey Through College of Seven Gifted Females: Influences on their Career Related Decisions, Roeper Review, 22(4), 21-261.

Headlam-Wells, J (2004), E-mentoring for Aspiring Women Managers, Women in Management Review, Vol 19, Number 4, MCB UP Ltd, pp 212-218. 
Headlam-Wells, J, Craig, J and Gasland, J (2006), Encounters in Social Cyberpace, E-Mentoring for Professional Women, Women in Management Review, Vol 21, No 6, MCB UP Ltd, pp. 483-499.

International Labour Organization(1998), Will the Glass Ceiling Ever be Broken? Women in Management, it's Still Lonely at the Top, the World of Work No 23, February 1998.

Jamali D, Safieddine, A and Daouk, M (2006), The Glass Ceiling: Some Positive TrendsFrom The Lebanese Banking Sector, Women in Management Review, Vol, 21, No.8, pp 625642.

Jawahar, I.M, Hemmasi, P (2006), Perceived Organizational Support for Women Advancement and Turnover Intentions, Women in Management Review, Vol. 21, No 8, pp 643-661.

Jayaweera, S (2000), Trends in Employment, Post Beijing Reflections: Women in Sri Lanka 1995-2000, CENWAR, Colombo.

Jayaweera, S and Wanasundera, 1 (2006), Inclusion or Exclusion? Gender and ICT in SriLanka, Colombo: Centre for Women's Research.

Jayaweera, S and Wanasundera, 1 (2006), Inclusion or Exclusion? Gender and ICT in SriLanka, Colombo: Centre for Women's Research.

Jayaweera, S and Wanasundera, 1 (2006), Inclusion or Exclusion? Gender and ICT in SriLanka, Colombo: Centre for Women's Research.

Lawthom, R, Patterson, M, West, M, and Staniforth, D (1996), Women Managers' Views of Manufacturing: Nice Work?, Women in Management Review, Volume 11, Number 6, pp 310, MCB UP Ltd.

Leung, A.S.M and Clegg, S.R (2001), "The Career Motivation of Female Executives in the Hong Kong Public Sector”, Women in Management Review, Volume 16,Number 1, pp 12-20, MCB UP Ltd.

London, M (1983), “Toward a Theory of Career Motivation”, Academy of ManagementReview, Vol. 8, No.4, pp 620-30. 
Marshall, J (1984), Women Managers: Travelers in a Male World, John Wiley and Sons, Chichester.

Moore, S, Sikora, P, Grunberg, L and Greenberg, E (2007), Managerial Women and theWorkHome Interface: Does Age of Child Matter? Women in Management Review, Vol 22, No 7 , MCB UP Ltd, pp 568-587.

Moore, S, Sikora, P, Grunberg, L and Greenberg, E (2007), Managerial Women and theWorkHome Interface: Does Age of Child Matter? Women in Management Review, Vol 22, No 7, MCB UP Ltd, pp 568-587.

Pulkkinen, L, Ohranen, M, Tolvanen, A (1999), "Personality Antecedents of CareerOrientation and Stability among Women Compared to Men", Journal of Vocational Behaviour, Vol. 54, No 1, pp 37-58.

Rana, B.K, Kagon, C, Lewis, S, Rout, U (1998), British South Asian Women Managersand Professionals: Experiences of Work and Family, Women in Management Review, Volume 13, Number 6, pp 221-232, MCB UP Ltd.

Ratnasabapathy, S (2006). Women's Under Representation in Construction: Barriers to Recruitment and Retention, Paper Presented at the Tenth National Convention on Women's Studies $2^{\text {nd }}-5^{\text {th }}$ April 2006, Colombo, Center for Women's Research.

Straub, C (2007), A Comparative Analysis of the Use of Work-Life Balance Practices inEurope, Women in Management Review, Vol 22, No 4, MCB UP Ltd, pp 289-304.

Yin, R.K (2003), Case Study Research: Design and Methods (Third Eds.., Rev), Thousand Oaks, CA: Sage Publications.

Zunker, V.G (2002), Career Counseling: Applied Concepts of Life Planning (6 ${ }^{\text {th }}$ ed), Pacific Grove, CA: Brooks/Cole. 